\title{
脳性まひ児の立位姿勢の安定に及ぼす動作訓練の効果
}

\section{—— 光学的配列の流動により引き起こされる身体動摇を指標として——}

\begin{abstract}
干川隆
本研究の目的は、脳性まひ児の立位姿勢に及ほす動作訓練の効果を検討することであっ た。 8 歳 11 か月（研究開始時）の被験者は、一人で歩くことができたが、転びやすかった。 被験者は、約 4 年間に計 135 セッションにわたり動作訓練を受けた。立位姿勢の指標として、 傾く部屋による光学的配列の流動によって引き起こされる身体動摇が、3 回にわたり重心計 により測定された。訓練の経過は、動作訓練課題によって4つの段階に分けられた。動作訓 練による変化として、1）訓練セッションにおける立位や歩行姿勢の改善、2）転ばなくなっ たなどの日常生活での改善、3）重心計上での身体動摇の減少と制御できる範囲としての踏 みしめ域の拡大、4）傾く部屋による身体動摇への影響の減少、が明らかとなった。本研究の 知見は、動作訓練による自体操作の変化がアフォーダンスの知覚に影響を及浔すことを示唆 するであろう。
\end{abstract}

キー・ワード：脳性まひ児 動作訓練 光学的配列の流動 身体動摇 アフォーダンス

\section{I . 問題と目的}

これまで、脳性まひ児の認知機能の障害は、(1) 非可 逆的な中枢神経系の障害、(2) 環境情報を受容する感 覚末梢器官の障害、(3) 身体運動機能が制限されてい ることからくる二次的な認知活動の不足、による要因 が指摘されてきた（山内・門前・成瀬, 1974）。脳性ま ひという障害の複雑さのために、これらの要因を分離 して明らかにすることは難しい。結果的に、従来の研 究の中で(1)と(2)の要因が検討されてきたが、(3)の要因 を検討した研究も報告されるようになってきた（干川， 1993; 干川・大神, 1989; 佐藤, 1986; Wedell, Newman, Reid, \& Bradbury, 1972)。これらの研究は、行為（姿 勢の保持や移動など）と知覚との関連を被験者間で検 討したものと、行為が変化したときに知覚がどのよう に変化したかを被験者内で検討したものとに分けるこ とができる。前者の研究のうち Wedell ら（1972）は、 大きさの恒常性が脳性まひ児の生活年齢ではなく、一 人で移動できるようになってからの経験の長さに関連 していることを示した。また佐藤（1986）は、脳性ま ひ児の身体の緊張と垂直判断の逸脱の方向が感覚-緊 張場理論に従うことを示した。さらに干川（1993）は、

熊本大学教育部
自分の身体を基準としたときあるいは人形を基準とし たときの上下左右前後などの方向指示の得点が、寝た きり群よりも立位・歩行群のほうが高かったことから、 動作レベルが高いほど方向指示が正確であることを示 した。

一方、後者の研究は、個人内の変化を生み出す方法 として脳性まひ児の被験者に対して動作訓練を用いて きた。動作訓練は、脳性まひ児の動作不自由の分析か ら、「意図-努力-身体運動」の一連の心理過程を「動 作」と定義し、心理学的な立場から動作変容を目的と した指導法である（成瀬, 1973）。今日、動作訓練によ る姿勢や動作の改善の事例報告は枚挙にいとまがない （例えば、干川, 1987; 谷, 1993）。その中で、佐藤 (1986) は 2 名の脳性まひ児に対して動作訓練を実施し、緊張 が軽減し立位姿勢が安定するにつれて垂直判断の誤差 が小さくなり試行間の標準偏差 (SD) も小さくなるこ とを示した。一方、干川・大神（1989）は、4名の脳性 まひ児に対して姿勢の変化をとらえる客観的な指標と して重心計を用いて動作訓練の前後の姿勢と垂直判断 の関連を検討し、訓練後に垂直判断が正確になったも のの、重心動摇に個人差のあることを示した。

従来、知覚と行為との相互作用を検討した研究は、 その相互作用を説明するために何らかの表象を想定し 
なければならなかった。しかし、表象そのものを直接 に検討することができないことから、表象によらずに 知賞と行為との相互作用を説明すべきであるとする生 態学的アプローチがある (Reed, 1988)。生態学的アプ ローチの立場に立つと、知賞と行為とを別々に検討す るのではなく、視覚と姿勢とに同時に影響を及ほす情 報が提示される状況の中でこの相互作用を検討するこ とが必要とされる。

知覚と行為との相互作用を検討するためのひとつの 方法は、光学的配列の流動による姿勢への影響に関す る研究である。光学的配列の流動は、遠近法的構造を もち、その流動によって人は対象の動きだけでなく自 分自身の動きをも知覚することができる (Gibson, 1979）。この光学的配列の流動による姿勢への影響は、 従来、ベクションの知覚に関する研究や、誘導される 自己の運動感賞に関する研究として検討されてきた (Dichgans \& Brandt, 1978; 狩野, 1991 を参照)。光学 的配列の流動が運動感覚と同様な情報を提供すること は、Leeとその同僚によって検討されてきた（Lee \& Aronson, 1974; Lee \& Lishman, 1975; Lishman \& Lee, 1973)。Lee らの実験は、「動く部屋」と呼ばれる 装置を用いたものであった。この装置では、観察者は 動かない床の上で、前後に動く三方の壁と天井に囲ま れて立っていた。たとえば、前方への部屋の動きは、 観察者に身体が後ろに倒れるかのような光学的配列の 流動を生じ、動きと同方向の身体動摇を生じた。

それでは動く部屋は、障害のある子どもの立位姿勢 にどのように影響を及ほすのであろうか。先行研究 は、わずかにダウン症児と脳性まひ児を被験者として 検討した研究だけである。Butterworth and Cicchetti （1978）は、29.8 か月から 41.8 か月（立位保持の年齢 が 1.25 か月から 19.5 か月）のダウン症児と立位経験 の月歯が対応した障害のない被験者（14.0か月から 34.1 か月）に動く部屋を用いて姿勢に及济す視覚の影 響を検討し、ダウン症児が障害のない子どもよりも立 位で視覚的な影響を受けること、立位経験が多くなる につれて視覚的な影響を受けなくなることを示した。 一方、Nashner, Shumway-Cook, and Marin (1983) は、支持面と視覚的な流動の両方が移動したときに脳 性まひ児が姿勢に影響を受けること、特に運動失調型 の脳性まひ児が倒れてしまったことを示し、運動失調 型の脳性まひ児が主に感覚組織に障害をもつためであ るとしてその原因を考察した。しかし今までの動く部 屋を用いた研究は、同一被験者の中で訓練によって姿 勢が安定したときに、光学的流動がどのように身体動
摇に影響を及ぼすかについては検討していない。 そこで本研究は、一人の脳性まひ児を対象として動 作訓練の過程での光学的配列の流動が身体動摇に及ほ す影響を調べることを目的とした。著者は研究に先立 ち、1）動作訓練により立位姿勢が安定するであろう、 2）脳性まひ児も先行研究と同様に光学的配列の流動 と同方向に身体動摇を生じるであろう、3）立位姿勢 の安定に伴い光学的配列の流動による立位姿勢への影 響が減少するであろう、と予測した。

なお、Lee らは動く部屋により生じる光学的流動の 姿勢に及ぼす影響を検討するために、前後に動く部屋 を用いてきたが、本研究では、Nashner, Black, and Wall（1982）を参考に、被験者の足首関節の位置を軸 として前面と両側面の壁と天井が前後にわずかに「傾 く部屋」（干川, 1998）を実験装置として用いた。なぜ なら、前後の動きはかなり大がかりな実験室ならびに 実験装置を必要とすること、部屋が傾く実験装置のほ うが立っている被験者に自分が前後に倒れるという錯 覚を生じやすいと考えたからであった。

\section{II. 方 法}

\section{1. 動作訓練による対応}

1) 被験者： 被験者は、1人で立位歩行ができる 脳性まひ (アテトーゼ型) と診断された女性 $\mathrm{A} さ ん$ (以 下A）であった。A は 8 歳 10 か月（小学校 3 年）のと きに教育相談に来所した。そのときの主訴は、転びや すいなどの歩行の不安定さ（保護者は A の姿勢の不 安定さについて「筋がひとつ通っていない」と表現し ていた)、言葉が不明瞭であること、手先の不自由さで あった。

2) インテーク時の動作状況：インテーク時の 立位姿勢の様子は、Fig. 1 左に示す通りである。A は、 效を前に出し頭を後方へ傾けがちであった。話したり するときには不随意的に腕に力が入ってしまい手が上 がりがちであったが、下げようとすると腕を突っ張り ながら下げることができた。A は、歩くときには脚が 突っ張り、片足に体重を乗せずに次の足を出すロボッ トのような歩き方であり、片足で立つことはできなか った。A は、今まで療育センターでの訓練や保育所で のリズム運動による成果から、著しい慢性緊張や姿勢 の歪みはなく、また、身体を一緒に動かすことにも抵 抗がなかった。著者（援助者として直接に A にかか わってきたことから、以下トレーナー)の A の動きに 対する印象は、著しい慢性緊張や姿勢の歪みはないも のの、何かしょうとすると当該以外の部位が動いてし 

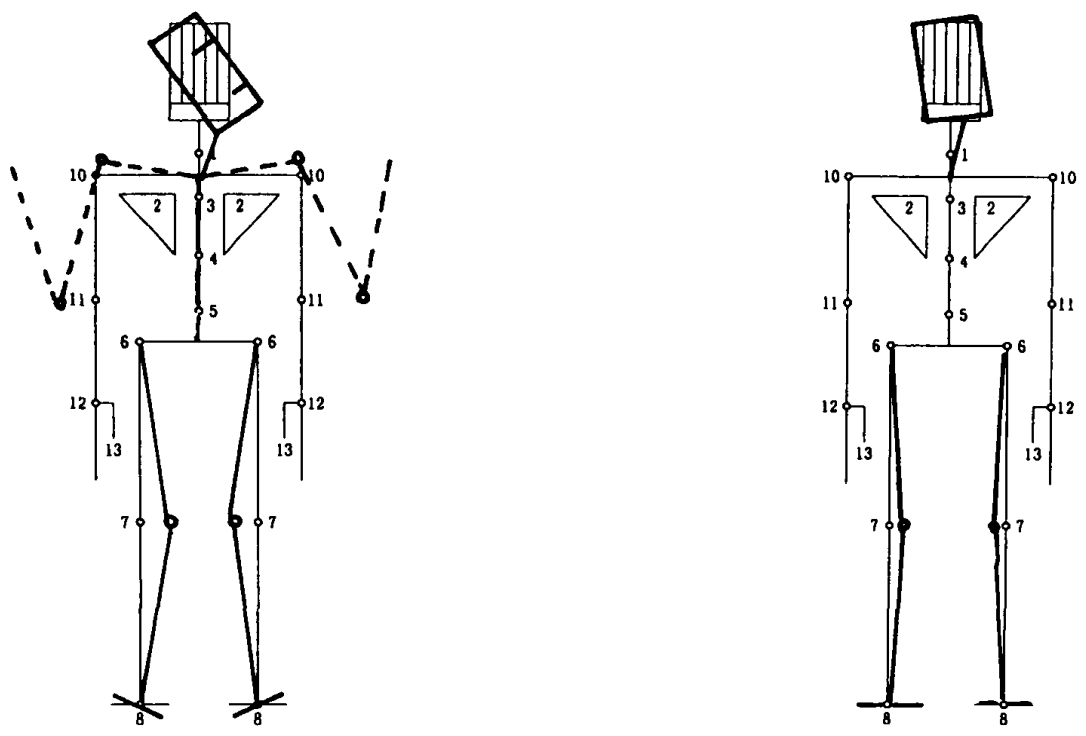

Fig. 1 動作訓練の前後のボディダイナミックス図

まうというような微妙な体のコントロールに課題を残 しているといった感じであった。

\section{2. 傾く部屋の身体動摇への影響の測定}

1) 装置：装置は高さ $180 \mathrm{~cm}$ 、幅 $180 \mathrm{~cm}$ 、奥行 き $90 \mathrm{~cm}$ の部屋であり、部屋の開いた側の端を支点と して前後にそれぞれ $12^{\circ}$ 傾けることができた。この部 屋の内面は、光学的流動を強調するため、 $10 \mathrm{~cm}$ 四方 の白黒の格子模様でおおわれていた。被験者の目の高

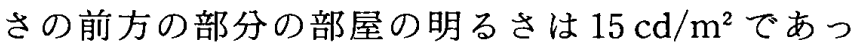
た。部屋の傾きの角度は、支点につけられたポテンシ ヨ・メーターにより測定された。また、部屋はエアー・ ジャッキにより $0.40 \sim 0.46 \mathrm{deg} . / \mathrm{s}$ の速度でゆっくり と傾くものであった。

身体動摇は、重心計（三栄測器製三点支持重心計

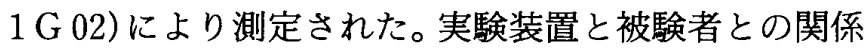
は Fig. 2 に示す通りである。重心計上で被験者の両足 は、 $10 \mathrm{~cm}$ 間隔で平行になるようにし、その中心線と 両足の舟状骨を結ぶ線分（数理的重心点）が重心計の 中心になる位置に合わせられた。重心は、X(左右)方 向、 $\mathrm{Y}$ (前後) 方向、それに重心計への荷重量を示す Z （上下）方向の 3 成分に分けて出力された。押しボ夕 ン・スイッチ、ポテンショ・メーター、重心の X、Y、 $Z$ の値は、日本光電製脳波計 (EEG 5213) で増幅され、 データ・レコーダー（SONY A-614）に記録された。 押しボタンスイッチは、処理のためのトリガーとして 用いられた。データ・レコーダーに記録されたデータ

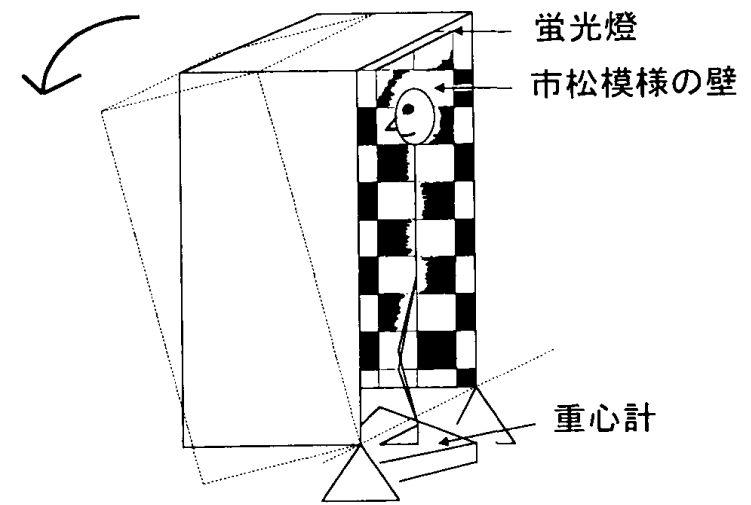

Fig. 2 「傾く部屋」の奏験装置と被験者との関係

は、A/D コンバーター(カノープス電子製 ADX-98 H) を介して $10 \mathrm{~ms}$ 単位で $\mathrm{A} / \mathrm{D}$ 変換された後、パーソナ ル・コンピューター（NEC PC-9801 UX）により処理 された。

なお、重心計により測定される重心は、前後 $(\mathrm{Y}) 、$ 左右 $(\mathrm{X})$ と荷重量 $(Z)$ の積で出力されているため、 荷重量（被験者の体重）による影響を受けた。体重の 違いを排除するために、重心の分析は、出力されたモ 一メント出力を $Z$ 出力で除して、身体動摇を長さとし て算出したものを用いた。

2 ）手続き：测定は、被験者の実験状況への慣れ による影響を最小限にするために、長期 (1 年半) の間 隔を空けて 3 回のみ実施した。測定 1 は訓練課題に慣 れてきた時期（セッション 14 : 被験者が 9 歳 2 か月 
時)、測定 2 は 1 年半後（セッション $73: 10$ 歳 8 か月 時）であり、測定 3 はさらに 1 年半後（セッション $122 ： 12$ 歳 2 か月時) であった。

重心の測定は、大学内の実験室で行われた。測定の 流れは(1)ベースラインの測定、(2)傾く部屋による実 験試行（5 試行）、であった。なお、測定 2、測定 3 の 折には、(1)の後に(3)踏みしめ域の測定、を加えた。

(1)のベースラインの測定で被験者は、目の高さに貼 り付けられた画鋲 (直径 $1 \mathrm{~cm}$ )を見ながら直立に立ち、 手足を動かさないで 1 分間直立姿勢を維持するように 求められた。(2)の傾く部屋による実験試行では、「前方 の目の高さの位置に置かれた画鋲をずっと見つめて、 身体を前後左右に動かさないでまつすぐに立つよう に」との教示が与えられた。各試行で 10 秒間の静止 した立位での重心の測定、約 30 秒間の部屋全体が前 方に約 $12^{\circ}$ 傾く状況での重心の測定、さらに 10 秒間の 静止した立位での重心の測定が行われた。(2)の傾く部 屋による実験試行では、被験者が倒れたときに備えて、 被験者の後ろから倒れたときに補助するための補助者 が待機していた。

(3)の踏みしめ域の測定では、被験者はからだ全体を 一本の棒のようにまっすぐに保持し、足の裹を離さな いで足首を軸として身体を前後左右に大きな角度で傾 けた姿勢を保持するように求められた。測定の䐓序 は、その都度中心に戻すようにしながら前後左右の順 で 4 方向、それぞれの位置で 1 回ずつ 5 秒間保持して 测定が行われた。踏みしめ域は、被験者が重心計上で 身体を前後左右に傾けて踏みしめることのできる範囲 として定義された。これはLee らの知見から、被験者 が踏みしめることのできる範囲が広いほど姿勢が安定 していると考えたからである。

\section{III. 経過と結果}

\section{1. 功作訓練の経過}

指導の目標は、立位姿勢の安定と歩容の改善であっ た。動作訓練は、タテ系動作訓練(成瀬, 1991)に従い、 あぐら坐位、膝立ち位、片膝立ち位、立位、歩行で重 力に応じて自体を操作する課題が中心であった。上述 の課題の合間に、腕や手の使い方、舌などの口回りの 使い方の課題を加えた。動作訓練によるセッション は、夏休みなどの長期休昵の期間を除き原則として週 に 1 度、 $\mathrm{A}$ が 8 歳 10 か月から 12 歳 9 か月までの 3 年 11 か月にわたる計 135 回であった。1 セッションの長 さは、45 分から 50 分であった。動作訓練による経過 は、動作訓練課題の移行に伴い 4 期に分けることがで
きた（Table 1)。

なお、動作訓練による経過は実施後にその課題の推 移によって 4 つに分けたのに対し、測定は機械的にそ の時期を設定したために、測定 1 が第 1 期、測定 2 が 第 3 期、測定 3 が第 4 期となり、3 回の測定と経過の 4 期とはセッション数が異なっていた。

1）第 1 期一自体への気づき期（セッション 1 から 15）：頢を前に出し、頭を後方へ傾ける、膝立ち 位で腰を落とそうとすると上体を前傾し腰を引く、腰 を上げていくと上体を後ろに倒し突っ張ってしまうな どにみられるように、A は姿勢保持や移動動作の中で 身体が勝手に動いてしまうと捉えていた。動作訓練課 題では、ひとつひとつの自分の身体（自体）に気づき ながら、姿勢を維持し、操作できることを目的とした。 具体的には、頭が斜めになってしまうことからあぐら 坐位で、顎を引くようにして首の後ろの緊張を弛め る、弛めた状態を保持する、頭の位置をまっすぐに保 持しながら腰を動かすことをトレーナーが援助しなが ら行った。また、膝立ち位では、直立位から股を折っ て腰を引かせて停め、その位置から元の直立位まで腰 から上体を前へ平行移動させる課題（腰の落し停め立 ち上がり課題）で、上体を前傾して勢いをつけたり反 らしたりせず、腰や股関節に注意を向けながらじっく り動かすことを動作課題として設定した。しかし、A は思うように身体が動かないことから、トレーナーに 対して今行っている課題と関係のないことを話しかけ ることが多く、細かな身体の操作を意識して行うこと までは難しかった。この期は、広く浅く課題を行うと いった状況であった。

2 ）第 2 期一自体の気づきの拡大と自体操作の 明確化期（セッション16から 51）：セッション中課 題と関係のない話をすることが多かったが、A はトレ ーナーと話すことを楽しみに来所していた。また、話 している割には、立位時や歩行時の姿勢に変化がみら れはじめたことから、話しながらでも $\mathrm{A}$ が動作課題 を通じて自体への気づきを増やしていることが推測さ れた。第 2 期では、身体を操作する上で支障となる緊 張を弛める課題を加えた。具体的には、あぐら坐位で の前届による股関節を弛める課題、上体の反らせと左 右にひねる課題、片膝立ち位で出し脚の股関節を弛め て支持脚に力を入れる課題であった。この期を通じ て、A は自分で緊張している部位に気づき、援助され ながらその部分を自ら弛めることができ、あるいは片 膝立ち位に代表されるように力を入れる部位と抜く部 位がより明確になっていった。その結果、A は立位の 
Table 1 主な動作課題の推移（○重点課題， ○課題）

\begin{tabular}{|c|c|c|c|c|}
\hline & $\begin{array}{l}\text { 第 } 1 \text { 期 } \\
\# 1 \sim 15\end{array}$ & $\begin{array}{l}\text { 第 } 2 \text { 期 } \\
\# 16 \sim 51\end{array}$ & $\begin{array}{c}\text { 第 } 3 \text { 期 } \\
\# 52 \sim 117\end{array}$ & $\begin{array}{c}\text { 第 } 4 \text { 期 } \\
\# 118 \sim 135\end{array}$ \\
\hline \multicolumn{5}{|l|}{ あぐら坐位 } \\
\hline 顎を引いて弛める & (C) & & & \\
\hline 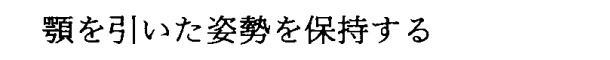 & (O) & & & \\
\hline 額を引きながら腰を前後に動かす & (0) & 0 & 0 & 0 \\
\hline 上体の前届（股弛め） & & () & $\bigcirc$ & $\bigcirc$ \\
\hline 上体の反らせ & & (O) & 0 & 0 \\
\hline 上体のひねり & & (O) & 0 & 0 \\
\hline \multicolumn{5}{|l|}{ 膝立ち位 } \\
\hline 腰の落し停め立ち上がり & (0) & () & () & () \\
\hline 左沝・右膝での踏みしめ & 0 & (O) & () & (O) \\
\hline \multicolumn{5}{|l|}{ 片膝立ち位 } \\
\hline 股ゆるめ & & (2) & & \\
\hline 前後方向への平行移動 & 0 & 0 & O & () \\
\hline 腰の位置を水平にして保持し, 動かす & & O & O & (9) \\
\hline \multicolumn{5}{|l|}{ 立位 } \\
\hline 膝の凮げ伸ばし & (2) & () & $\bigcirc$ & O \\
\hline 足の前で踏みしめる & (O) & (O) & (O) & () \\
\hline 足の外側で踏みしめる & & & (O) & (O) \\
\hline 左脚・右脚で踏みしめる & & & 0 & () \\
\hline 片脚上げ & & & O & (0) \\
\hline \multicolumn{5}{|l|}{ 歩行 } \\
\hline \multicolumn{5}{|l|}{ 腰の位置を平行に維持しながら歩く } \\
\hline 後ろ足を蹴った勢いで前に出す & & & O & () \\
\hline 股を伸ばして歩く & & & 0 & (2) \\
\hline \multicolumn{5}{|l|}{ 手 } \\
\hline 腕の回外 & 0 & 0 & O & $\bigcirc$ \\
\hline 时伸ばし & $\bigcirc$ & O & O & O \\
\hline 指の開閉 & O & O & 0 & 0 \\
\hline \multicolumn{5}{|l|}{ 口 } \\
\hline 舌の出し入れ（䫟の下の弛緩） & (O) & (2) & $\bigcirc$ & O \\
\hline
\end{tabular}

膝の屈げ伸ばし課題で、上体を前後に傾けずに膝を凰 げるー伸ばすことが確実にできるようになっていった。

3 ）第 3 期一一応重力姿勢での自体操作の拡充期 （セッション 52 から 117）：この期では、今までの動 作課題に加えて、膝立ち位、立位での踏みしめ課題に よる自体操作の拡大を中心的課題として行った。膝立 ち位で、A は前後の調整から左右の膝それぞれで踏み しめる中で、それぞれの脚に体重をのせタテに力を入 れて踏む感じを明確にした。立位では、A は足の前の ほうで踏むことに加えて、それぞれの脚で足の内側と 外側で踏む感じが区別できるようになっていった。そ れぞれの脚で前後左右で踏みしめられる範囲が広くな
り、A は片脚で立っても、前後左右を区別して踏むこ とができるようになった。それに伴い、片脚を上げて も 10 秒以上立位姿勢を保持できるようになった。

4) 第 4 期一一移動動作での自体操作の拡充期 （セッション 118 から 135）：立位姿勢が安定したこ とから、第 4 期ではその成果を歩容に生かすことが中 心的な課題であった。A は足を上げて前に出すとき に、浮遊相にある脚の腰をフニャッと下げてしまい、 支持脚の腰を後ろに引いてしまう。このため、トレー ナーは膝立ち位と片膝立ち位で A が腰の位置を絶え ず意識し、腰を下げたときと平行に維持しているとき とを区別するように援助した。こうすることにより歩 
行時に、A が腰を上下に移動する程度が少なくなっ た。さらに、Aは脚 (特に右脚)を外側に半円を描くよ うに出していた。このため、後ろの脚を蹴ってその勢 いで前にまっすぐ脚を出すことを課題として加えた。 A は、歩行という移動動作の中でトレーナーによる言 語指示やわずかな援助により、その部位を意識し姿勢 を修正できるようになった。

5 ) 動作訓練による成果：動作訓練による目に 見える成果として、保護者や $\mathrm{A}$ の報告と観察から、(1) 転ぶことが少なくなった、(2) 歩行時の姿勢がふらふら せず安定した、(3)片足で 10 秒ほど立つことができる ようになった、があげられる。訓練後の立位姿勢は Fig. 1 の右に示す通りである。Fig. 1 に示すように、A は立位姿勢が安定し、肩に力を入れることが少なくな り腕に力を入れずに立つことができ、また足の外側で 踏みしめることができるようになった。

\section{2. 重心計による身体動摇の測定結果}

1) 立位姿勢時の身体動摇の変化：まずベース ラインの測定の結果として、立位時の身体動摇の変動 は、Fig. 3 に示されている。これは、傾く部屋の前に開 眼で 1 分間立位姿勢を維持したときの前後の身体動摇 の標準偏差值である。測定 1 を 100 とすると、测定 2 では 65.1 、測定 3 では 9.1 と身体動摇が漸進的に減少 することが示された。

次に、踏みしめ域の測定結果は、Fig. 4 に示されて いる。踏みしめ域の測定は測定 2 と測定 3 で行われた ものであった。Fig. 4 に示すように測定 3 のほうが前 後左右に踏みしめ域が増加していた。測定 2 の踏みし め域を 100 とすると、測定 3 の踏みしめ域は 188.9 に 広がっていた。

2 ）傾く部屋の身体動摇に及ぼす影響の変化： 傾く部屋の身体動摇に及ほす影響を調べるために $2 つ$

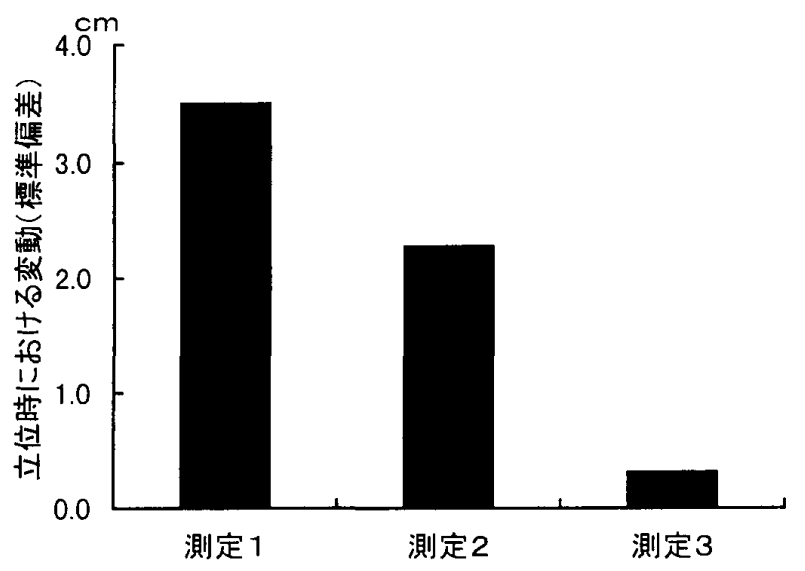

Fig. 3 立位姿勢時の身体動摇の変化
の指標を用いた。それは、実験セッションの部屋が傾 く前のベースラインからの平均の身体位置（平均身体 位置 mean body position：以下 MBP）と、ベースラ インを基準として部屋が傾く間に身体が最大に前方に 傾いた位置（最大身体動摇 maximum body sway：以 下MBS）であった（Hoshikawa, 1999 を参照)。

Fig. 5 は、MBS を示したものである。摇れの大きさ の違いはあるが、どの試行においても部屋の傾きと同 様に身体が前方に摇れることを示した。特に測定 1 で は、 5 試行のうち最初の 2 試行で被験者は姿勢を維持 することができず、傾きと同方向に倒れてしまい、補 助者による補助が必要であった。測定 1 の第 3 試行以 降、被験者は倒れることを用心して、MBP の位置を 後方に平均で $6.5 \mathrm{~cm}$ 移動して部屋の傾きに対応して いた。

動作訓練の効果として、傾く部屋の身体動摇に及ほ す影響をみるために、MBP と MBS との差を比較す ることにした（Fig. 6）。これはMBPと MBSとの差 が、部屋が傾く直前の値を基準としてどの程度前に傾 いたかを示すものであり、傾く部屋への順応の過程を

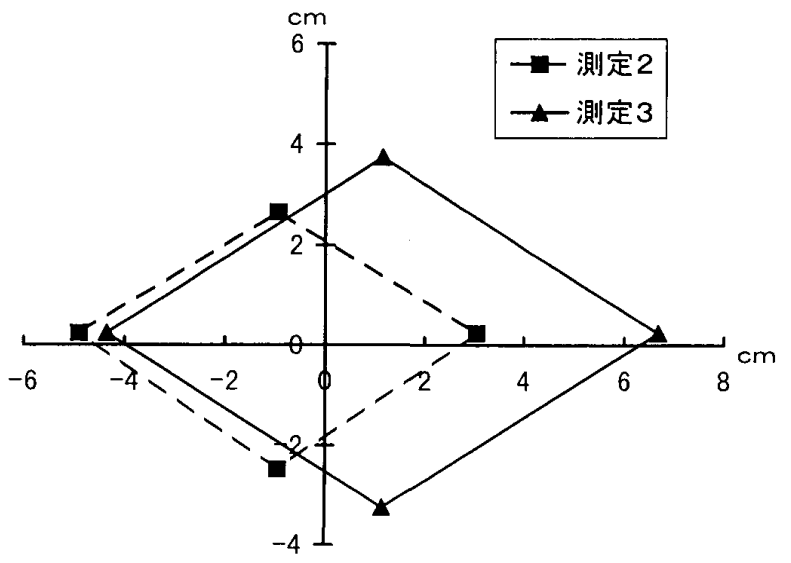

Fig. 4 測定 2 と測定 3 における踏みしめ域の変化

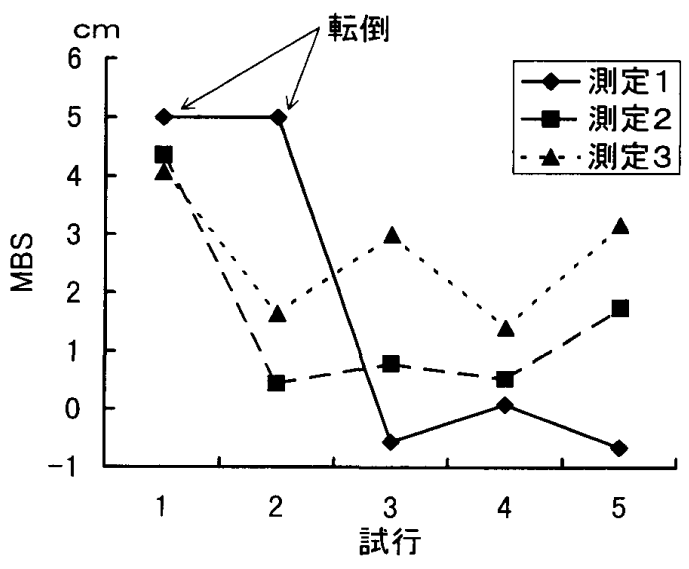

Fig. 5 MBS（最大身体動摇）の変化 
表す指標であるとされてきたからである（Hoshikawa, 1999)。MBP とMBS との差は、測定 1 (第 3 から第 5 試行) では平均で $6.3 \mathrm{~cm}$ 摇れたのに対して、 測定 2（第 1 から第 5 試行）の身体動摇の平均が 2.1 $\mathrm{cm}$ 、測定 3 (第 1 から第 5 試行）の身体動摇の平均は $3.3 \mathrm{~cm}$ であった。このように測定 2 では測定 1 と測 定 3 に比べると部屋の傾きによる影響は少なかった。 測定 3 では、全体として測定 2 よりも部屋の傾きによ り摇れるが、測定 1 よりもその影響は少なかった。

\section{IV. 考 察}

\section{1. 動作訓練による立位姿勢の安定について}

本研究の特徵のひとつは、訓練セッションにおける 立位や歩行姿勢の改善と転ばなくなったなどの日常生 活での改善に加えて、重心計を用いて変化の過程を明 らかにした点である。重心計によって、立位のときの 身体動摇が減少し制御できる範囲としての踏みしめ域 が拡大することが示された。姿勢保持と移動などの運 動との関連についてはさまざまな論議（例えば、 Reed, 1988）がある。谷（1993）は、タテ系動作訓練 における自体操作と「移動動作」との関連について、 垂直に力を入れられるようになることと、バランスと り能力の獲得・向上などの自体操作能力の変化が、水 平方向への「移動動作」能力と関連すると考察した。 本研究の結果は、重心計を用いバランスとり能力を踏 みしめ域の変化として定量化することにより、谷の知 見を支持するものである。

それでは、踏みしめ域という指標のもつ意味は何で あろうか。これまで脳性まひ児の立位姿勢の変化につ いて、重心計を用いた重心図により手術や補装具の効 果が示されてきた（月村・川村・羽根田・山下・池田・ 山村・安藤, 1975; 月村・小沢・川村・池田・柘植, 1980)。 そこでは主に両足や片足での重心変動面積の測定囲繞 面積に対する百分率や、仮定固有重心位置における Y 座標の足長に対する百分比などが指標として用いられ てきた。本研究の立位時の身体動摇の標準偏差は、こ れらの尺度と同様に静止した立位姿勢の指標である。 これに対して、月村らは片脚に対する重心の左右動摇 性を検討してはいるが、「バランスとり能力」を表して はいない。本研究で用いた踏みしめ域は、膝立ち位や 立位といった静的な姿勢でありながら重力に応じて環 境に能動的に働きかけているということから、移動動 作に向けた自体操作としてバランスとり能力などを評 価する有用な指標であるに違いない。

\section{2. 動作訓練による立位姿勢の変化と光学的配列の} 流動の知覚（アフォーダンス）との関連

本研究のもうひとつの成果は、上述の姿勢変化に加 えて、知覚との関連を検討した点である。結果は、動 作訓練によって傾く部屋による光学的配列の流動の立 位姿勢に及ぼす影響が減少することを明らかにした。 では重心計上に示される立位姿勢の安定と光学的配列 の流動により引き起こされる身体動摇との関連をどの ように考えたらよいであろうか。

ここではアフォーダンス (Gibson, 1979) による考察 を試みたい。Gibson は包囲光配列に備わり、人に意味 を直接に知覚させるものをアフォーダンスという言葉 で表した。アフォーダンスは、Gibson が記述したよう に、ある行為の可能性を有機体に提供し供給する活動 性であり、行為の可能性は、環境の特性と有機体の行 為システムの特性との一致によって決定されるのであ る。今までのアフォーダンスに関する研究の多くは、 被験者間での自己と環境との相互作用を検討し、その 法則性について検討してきた（例えば、Warren \& Whang, 1987)。本研究のように同一被験者内で自己 (の行為)が変化したときの知覚の変化について検討し たアフォーダンスの研究は皆無である。測定 1 （第 1 、 第 2 試行）では、被験者は部屋の傾きと同方向に倒れ てしまっていた。この試行では傾く部屋による光学的 配列の流動は、被験者にとって「倒れること」をアフ オード（提供・供給）していたのであろう。測定 $2 、 3$ では部屋の傾きは、倒れるほどの影響を及ほしていな かった。動作訓練場面での姿勢の安定と重心計に示さ れた身体動摇の減少から考えると、自体操作能力が向 上し立位姿勢が安定したことにより、同じ光学的配列 の流動にさらされたとしてもその情報は被験者に「倒 れること」ではなく「摇れること」をアフォードして

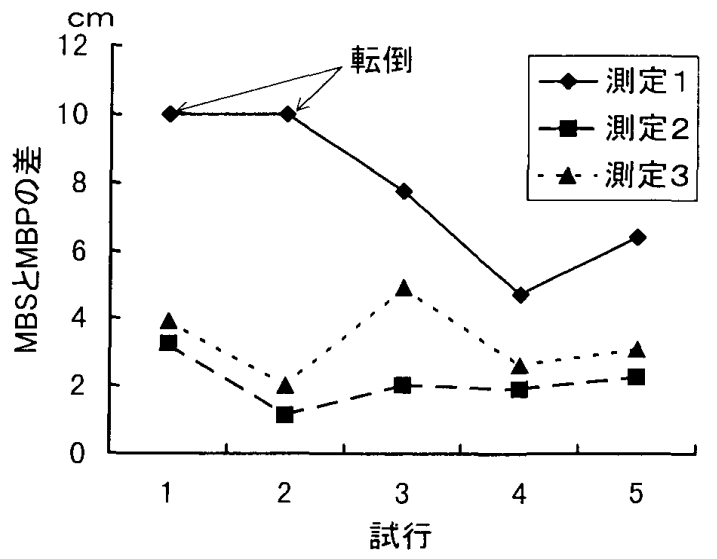

Fig. $6 \mathrm{MBP}$ (平均身体位置) と MBS (最大身体 動摇）との差の変化 
いたと推測される。この結果は、アフォーダンスが動 物と環境との相補性であることを示すものであり、さ らにアフォーダンスの知覚の背景にある自体操作の重 要性を示唆するものである。つまり、従来、知覚研究 では主に自己と環境との相互作用が検討されてきた が、物理的空間の中で重力に応じて自分の身体を能動 的に制御することは、その状況に合わせて適切に諸感 賞を統合しなおすことであり、その結果が環境の知覚 を変えるのであろう。

なお、著者は、測定 2 より測定 3 のほうが光学的配 列の流動による影響が少ないであろうと予測したが、 結果は逆に測定 3 のほうが光学的配列の流動による影 響を受けていた。同様の知見は、障害のない大学生を 被験者にして、動作訓練による踏みしめ域の増加と光 学的配列の流動の姿勢への影響の増加を示した干川 （1998）の結果から明らかである。したがって著者は、 踏みしめ域に示されるように、被験者が自分で制御で きる範囲の中で姿勢を保持しょうとしていたため、測 定 3 では測定 2 に比べて踏みしめ域が広がったことに よって、その範用の中で柔軟に制御できるようになっ た結果として、測定 2 よりも身体動摇が増したと推測 する。

今後、本事例でみられた動作訓練によって姿勢が安 定することで光学的配列の流動による立位姿勢への影 響が少なくなるという結果が、他の被験者でも同様に 生じるかどうかについて、被験者を增やして検討する ことが必要であろう。

\section{謝 辞}

本研究を実施するにあたりまして長い期間、被験者

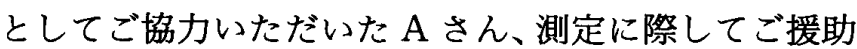
いただいた古川卓氏 (現琉球大学)、作成にあたりご指 導いただいた九州大学大学院人間環境学科教授大神英 裕先生に深く感謝いたします。

\section{文 献}

Butterworth, G. \& Cicchetti, D. (1978) Visual calibration of posture in normal and motor retarded Down's syndrome infants. Perception, 7, 513-525.

Dichgans, J. \& Brandt, T. (1978) Visual-vestibular interaction: Effects of self-motion perception and postural control. In R. Held, H. W. Leibowitz, \& H. L. Teuber (Eds.), Handbook of sensory physiology, Vol. 8. Springer-Verlag, Berlin, 755-804.

Gibson, J. J. (1979) The ecological approach to visual perception. Houghton Mifflin, Boston. 古崎敬 - 古崎 愛子・辻敬一郎・村瀬旻訳 (1985) 生態学的視覚論 一七トの知覚世界を探る。サイエンス社。

干川 隆（1987）一週間キャンプにおける膝立ち姿勢 の獲得過程ートレーナーの訓練方略の変容に伴っ て.リハビリテイション心理学研究，15, 33-44.

干川 隆（1993）脳性まひ児の方向概念の発達に関す る研究。特殊教育学研究, 30(5), 19-27.

干川 隆（1998）傾く部屋によって惹起される身体動 摇への身体の操作性と注意の影響.心理学研究，69, 310-316.

Hoshikawa, T. (1999) Effects of tilting room on body sway: Adaptation and strategies for maintaining a standing posture. Japanese Psychological Research, $41,186-192$.

干川 隆・大神英裕（1989）脳性まひ児における重心 の動摇と垂直判断の関連. 九州大学教育学部紀要 (教育心理学部門), 33(2), 151-158.

狩野千鶴（1991）自己運動知賞と視覚系運動情報。心 理学評論, 34, 240-256.

Lee, D. N. \& Aronson, E. (1974) Visual proprioceptive control of standing in human infants. Perception and Psychophysics, 15, 529-532.

Lee, D. N. \& Lishman, J. R. (1975) Visual proprioceptive control of stance. Journal of Human Movement Studies, 1, 87-95.

Lishman, J. R. \& Lee, D. N. (1973) The autonomy of visual kinesthesis. Perception, 2, 287-294.

成瀬悟策 (1973) 心理リハビリテイション。誠信書房. 成瀬悟策（1990）臨床動作法. 心理リハビリテイショ ン研究所.

Nashner, L. M., Black, F. O., \& Wall, C., III (1982) Adaptation to altered support and visual conditions during stance: Patients with vestibular deficits. Journal of Neuroscience, 2, 536-544.

Nashner, L. M., Shumway-Cook, A., \& Marin, O. (1983) Stance posture control in select groups of children with cerebral palsy: Deficits in sensory organization and muscular coordination. Experimental Brain Research, 49, 393-409.

Reed, E. S. (1988) Applying the theory of action systems to the study of motor skills. In O. G. Meijer \& K. Roth (Eds.), Complex movement behaviour: 'The' motor-action controversy. North-Holland, Amsterdam, 45-86. 
佐藤 暁（1986）脳性マヒ児（者）における身体の緊 張布置と垂直判断との関連. 教育心理学研究, 34 , 73-78.

谷 浩一 (1993) 訓練課題としての自体操作の重要性 について一脳性まひ児とダウン症児を通しての一考 察. 特殊教育学研究, 31(1), 31-37.

月村泰治・川村碩涁・羽根田純 - 山下八重子・池田珠 江・山村 治・安藤優子（1975）脳性麻痺の重心図. 整形外科, 26, 733-744.

月村泰治・小沢八重子・川村碩涁・池田珠江・柘植久 美子（1980）重心図からみた脳性麻痺の治療・その 2. 整形外科, 31, 1201-1208.

山内光哉・門前 進・成瀬悟策（1974）様々な図形布
置における脳性マヒと正常児のミュラー・ライヤー 錯視. 九州大学教育学部紀要 (教育心理学部門), 19(1), 19-23.

Warren, W. H. \& Whang, S. (1987) Visual guidance of walking through apertures: Body-scaled information for affordances. Journal of Experimental Psychology: Human Perception and Performance, 13, 371-383.

Wedell, K., Newman, C. V., Reid, P., \& Bradbury, I. R. (1972) An exploratory study of the relationship between size constancy and experience of mobility in cerebral palsied children. Developmental Medicine and Child Neurology, 14, 615-620.

-1999.9.6 受稿, 1999.12.11 受理一 


\title{
Dohsa Training and Standing Posture of a Child with Cerebral Palsy: Body Sway Induced by Flows of Optical Array
}

\author{
Takashi HosHIKAwA \\ Faculty of Education, University of Kumamoto \\ (Kumamoto-shi, 860-8555)
}

\begin{abstract}
The purpose of the present study was to examine effects of Dohsa training on the standing posture of a child with cerebral palsy. The child, who was 8 years 11 months old at the beginning of the present study, could walk alone, but tended to fall down. Over 4 years, she had 135 Dohsa training sessions. Based on the training tasks, the Dohsa training process was divided into 4 phases. As an index of body control, body sway was induced by flows of optical array, using a tilting room; it was measured 3 times by a force plate. The following indices indicated improved control of her body after the training: (1) observations during training sessions, such as improved standing posture; (2) reports from parents and the girl herself, such as that she rarely fell down; (3) decrease in body sway and "Fumisime" area as the subject's standing ability, indicating that the controllable area had grown larger; and (4) decreased effect on body sway from the flows of optical array at the second and third measurements, compared to the first. These findings suggest that change of action through Dohsa training affects the perception of affordance.
\end{abstract}

Key Words: a child with cerebral palsy, Dohsa training, flows of optical array, body sway, affordance 